Meta

Journal des traducteurs

Translators' Journal

\title{
Comparative Analysis of Russian and American Humor
}

\section{Emil Draitser}

Volume 34, numéro 1, mars 1989

Humour et traduction

Humour and Translation

URI : https://id.erudit.org/iderudit/002585ar

DOI : https://doi.org/10.7202/002585ar

Aller au sommaire du numéro

Éditeur(s)

Les Presses de l'Université de Montréal

ISSN

0026-0452 (imprimé)

1492-1421 (numérique)

Découvrir la revue

Citer cet article

Draitser, E. (1989). Comparative Analysis of Russian and American Humor. Meta, 34(1), 88-90. https://doi.org/10.7202/002585ar d'utilisation que vous pouvez consulter en ligne.

https://apropos.erudit.org/fr/usagers/politique-dutilisation/ 


\section{COMPARATIVE ANALYSIS OF RUSSIAN AND AMERICAN HUMOR}

EMIL DRAITSER

Hunter College, New York, New York

Most Russian jokes are heavily political. It doesn't mean, however, that Russian people are obsessed with politics. Due to the nature of an authoritarian state, no matter what side of life a joke concerns, it becomes politicized. Not enough meat in the stores politics, streets are not clean - politics, antisemitism among Russian population - even more politics. But a joke's subject matter alone doesn't make it funny, its humorous concept does. That's why some Russian anecdotes, which seem quite Russian in content, can occasionally be transplanted to American soil and remain funny. Consider the following item:

Brezhnev is getting a haircut. As he clips away, a barber asks :

"Tell me, Leonid Illich, how are things going for us in Poland?"

Brezhnev numbles and fidgets in the chair. The barber continues asking:

"And what about Afghanistan, Leonid Illich? Are we there for long?"

Brezhnev again mumbles with displeasure.

"And tell me, Leonid Illich...", the barber started again.

A KGB officer comes up to him :

"Hey, you! What kind of questions are you asking Comrade Brezhnev? Are you out of your mind? Why do you keep upsetting him? Are you politically unstable? We'll check you out right now..."

"Oh no, no", the barber exclaims sincerely. "Please Comrade ! I wasn't even thinking of politics. I asked for strictly professional reasons. When the hair stands on end, it's so much easier to cut".

It's easy to see how this story could translate into an American context. Change Afghanistan to Nicaragua, Poland to Iran - and you'll get a Reagan joke. I doubt, however, that this joke would make rounds for a long period of time in the United States...not because of lack of people who disapprove of Reagan's international policy, in Central America, but because of the abundance of other, open means of criticism.

Let us compare American and Russian humor by subgenre. Some types of jokes, popular in America, never caught on in Russia for one reason or another.

1) There are no "Why did the chicken cross the road?" jokes in Russia. Perhaps because for the average Russian it's hard to imagine that a much-sought-after food item would wander unattended...

2) "Knock, knock jokes", popular in America, seem to be a perfect setting for humor, since the situation already has built-in suspense. "Who's there?" is as inviting to surprise as "around the corner" type cartoons. I've found very few Russian jokes with this setting, perhaps because the situation bears too painful a memory for Russian people, reminding them of the years of Stalin's terror with its mass arrests, usually conducted in the middle of the night.

3) "Elephant jokes" are similar to traditional Armenian jokes (the same element is present in the modern modification of this subgenre - Armenian radio). These jokes 
consist of a question and an answer that can't be guessed because of the absence of any clues. Most Armenian radio jokes are political in nature, like this one ridiculing the lack of reliable information in the Soviet Union:

Question to Radio Armenia: "Is it true that Comrade Agopian won one hundred thousand rubles on a lottery ticket?"

Answer: "It's true. But it wasn't Agopian, it was Ambartsumian. It wasn't one hundred thousand, but one hundred. It wasn't on a lottery ticket, but in a game of cards. And he didn't win - he lost".

4) Polish jokes as they are told in America would hardly enjoy much success in the Soviet Union. The built-in script on stupidity (a term suggested by Victor Raskin) invoked in these jokes would make them amusing to Russians regardless of the protagonists. However, having Poles as the imbeciles and stupid characters in these jokes would be puzzling. For Poles are seen in quite a different light over there. Despite all the hardship during recent years, Russians consider Poles better off from a material standpoint than the Russians are; in Russian eyes, Poles have an overall higher standard of living. Poles even have a Polish-born Pope sympathetic to their problems which is, in Russian eyes, the equivalent of having a Chief Commander of NATO, sympathetic to Russians.

Culturally, Poles are seen in Russia as more refined. Historically, they had stronger ties to the West (to France in particular) than to Russia. For educated Russians, contemporary Polish literature is considered as more innovative and daring than Russian literature. Such Polish writers as Janush Osenka, Anatol Potemkovski, Stephania Grozdenska, and others have greatly influenced the genre of Russian satirical short-short story that was reborn in the middle of the $1960 \mathrm{~s}$. Witty, sharply pointed, with daring subtext, these stories have been succesful in subtle satirical attacks on the shortcomings of Russian life. So, a Polish joke from Larry Wilde's collection: "What is the world's thinnest book? The History of Polish Culture" would fall flat in Russia. Most scripts on stupidity evoked in American Polish jokes are employed in Russian jokes about the civil war hero, Chapaer, and in the "chukcha" series.

5) By and large American jokes poking fun at alcoholics who get in all sorts of trouble when intoxicated have a common ring to Russian ears. However, there are some subtle differences:

A man called to the stationmaster.

"I left a bottle of Scotch on the train this morning", he said. "Was it turned in to the lost and found department?"

"No", said the master. "But the fella who found it was".

If a Russian heard this bit of American humor, he would think the joke implausible for two reasons. First, no Russian would leave a bottle of liquor unattended, especially one as expensive and sophisticated as Scotch, even for a short period of time. Second, drunk or sober, a Russian would never even think of calling a lost and found department to inquire whether the item was returned for fear of being called a clinical idiot.

Other differences between American and Russian jokes on alcoholics stem from the special place a drunkard occupied in the Russian consciousness. By and large, he is looked at as a nice guy, a "silly saint" (jurodivyj) rather to be pitied than judged. The very readiness to drink upon an offer is seen as a gesture of a man who has nothing to hide; he's instantaneously trusted. On the contrary, a teetotaler is the object of suspicion. A bottle of vodka is much more valued than the money it's worth; vodka is often called "liquid currency". 
6) American and Russian sexually explicit jokes are pretty much the same. It's even safe to say that the Russian ones are more explicit than American ones. It even seems that dirty Russian jokes are dirtier. In fact, some Russians entertain a point of view that no dirty joke could be too dirty. Indeed, Russian jokes of this type seem to be more graphic and descriptive, perhaps in an attempt to fill the void of erotica in the absence of pornographic movies and magazines (either hard or soft) or even exposure to female beauty, Playboy style. For the same reason, it also seems that this type of Russian joke is overall not so much witty as informative. It looks like sexual tension in these jokes is higher, imagination runs wilder and situations are more bizarre. Some examples of Russian dirty jokes are contained in the book, Semantic Theory of Humor by Victor Raskin. Read it and see for yourself, when it comes to sexual jokes, how semantic Russians can be.

As we have seen, observing the rich body of Russian folklore one would undeniably find that Russia is not the most destitute place on earth when it comes to humor. Russians and Americans compete not only in the space and arms race, but in the field of the ludicrous. To illustrate, let me end these notes with the following Russian anecdote :

After the successful Apollo-Soyuz space flight, Leonid Brezhnev called to congratulate the cosmonauts. However, he also reproached them with, "The Americans are winning the space race. We must accomplish something to outdo them. They've already landed on the moon, so we in the Politburo have decided to send you for a landing on the sun".

The Cosmonauts groaned, "But Comrade Brezhnev, we'll be burned alive !"

"What do you think", interrupted Brezhnev, "that we don't understand anything? Don't worry, we've already planned all the details. First of all, you're going to complete the landing at night!"

BIBLIOGRAPHY

DRAITSER, Emil, (1980): Forbidden Laughter, Los Angeles, California, Almanal Press.

RASKIN, Victor (1985) : Semantic Mechanisms of Humor, Boston, Massachusetts, D. Reidel. 